УДК 371.302

DOI: 10.37026/2520-6427-2019-100-4-142-145
Тарас ГАЛАТЮК,

учитель фізики та інформатики

ЗОШ № 6 м. Рівного, магістр фізики,

здобувач Рівненського державного гуманітарного університету

Юрій ГАЛАТЮК,

кандидат педагогічних наук,

професор кафедри фізики, астрономії та методики викладання

Рівненського державного гуманітарного університету

\title{
ТВОРЧА ПІЗНАВАЛЬНА СИТУАЦІЯ ЯК ЧИННИК ФОРМУВАННЯ МЕТОДОЛОГІЧНОЇ КУЛЬТУРИ УЧНЯ
}

У статті розкривається дидактичний $і$ психологічний зміст творчої пізнавальної ситуації як механізму ініціювання творчої навчально-пізнавальної діяльності в контексті формування методологічноі культури учня. Аналізуються генезис та умови ї̈ виникнення. Розглядаються основні типи творчих пізнавальних ситуацій і способи їх створення.

Ключові слова: методологічна культура, творча пізнавальна ситуачія, творча навчальна діяльність.

В статье раскрывается дидактический и психологчческий смысл творческой познавательной ситуации как механизма инициирования творческой учебно-познавательной деятельности в контексте формирования методологической культуры ученика. Раскрываются генезис и условия ее возникновения. Рассматриваются основные типы творческих познавательных ситуаций и способы их создания.

Ключевые слова: методологическая культура, творческая познавательная ситуачия, творческая учебная деятельность.

The article is devoted to the problem of forming a methodological culture of students in the process of studying natural subjects. Methodological culture is an important category of natural education. It determines the success and effectiveness of the educational activity, is its means, subject and product.

The formation of a methodological culture of students is an urgent problem in the context of the implementation of the activity approach in the educational process of the modern school.

A priority type of educational and cognitive activity that ensures the formation of all components of methodological culture is creative educational and cognitive activity. This is especially true of its creative and productive components.

An important category concerning the design and organization of creative educational and cognitive activity is the creative cognitive situation.

The article reveals the didactic and psychological content of the creative cognitive situation. The mechanism of initiation of creative educational and cognitive activity in the context of formation of the student's methodological culture is explained. The genesis and conditions of its origin are revealed. The basic types of creative cognitive situations and conditions of their creation are considered.

The concept of creative cognitive situation does not duplicate the concept of problematic situation. It is broader and more meaningful in psychological and didactic aspects. This becomes clear when considering the concept of creative cognitive situation in the context of relevant psychological concepts of creative activity. The creative cognitive situation is a subjective category and is characterized by the presence of a cognitive dominant in the subject.

Key words: methodological culture, creative cognitive situation, creative educational activity.

Постановка проблеми. Організація освітнього процесу грунтується на проєктуванні та реалізації навчально-пізнавальної діяльності. Як засвідчують результати досліджень, будь-який вид діяльності має свою методологію. Водночас методологія - це вчення про організацію діяльності. На це звертає увагу Е. Юдін: «Методологія, яка трактується у широкому значенні цього слова, $є$ вченням про структуру, логічну організацію, методи і засоби діяльності. У такому розумінні методологія утворює необхідний компонент будь-якої діяльності, оскільки остання стає предметом усвідомлення, навчання і раціоналізації» [12, с. 20].

У літературних джерелах [5; 8], присвячених культурологічному підходу до організації освітнього процесу, наголошується, що ключовим атрибутом, особливістю людського існування $є$ культура, а найважливішим аспектом культури особистості методологічна культура. У центрі культури завжди перебуває людина, адже вона створює культуру, яка натомість формує особистість. Методологічна культура - це специфічна категорія, яка використовується не тільки в контексті методології науки, а й при аналізі індивідуального мислення, поведінки, діяльності людини. 
У результаті аналітичних розвідок нами було встановлено [2; 3], що методологічна культура учня відображає здатність прогнозувати й конструювати власну навчально-пізнавальну діяльність, здійснювати рефлексію навчально-пізнавальної діяльності, діагностику її результативності щодо розвитку та застосування нових компетентностей. У контексті вивчення природничих предметів методологічна культура учня $\epsilon$ важливим компонентом, що визначає успішність та результативність навчально-пізнавальної діяльності. Водночас методологічна культура - це інтегральна психолого-дидактична категорія, що відображає цілісне системне утворення, яке $є$ характеристикою суб'єкта навчально-пізнавальної діяльності, є предметом, засобом і прямим продуктом цієї діяльності, а також іiі регулятором [2; 3]. Учень під керівництвом педагога здійснює навчально-пізнавальну діяльність, є іiі суб' єктом та об'єктом, а отже, повинен володіти відповідним рівнем методологічної культури. Тому формування методологічної культури учнів $є$ актуальною проблемою в контексті реалізації діяльнісного підходу в освітньому процесі сучасної школи.

Запропонована нами модель методологічної культури учня в контексті вивчення природничих предметів становить ієрархічну систему, яку утворюють такі базові структурні компоненти: ціннісно-мотиваційний, гносеологічний, предметно-змістовий, інформаційно-комунікативний, морально-етичний, операційно-діяльнісний, креативний, естетичний, організаційно-рефлексивний, продуктивний [3].

Досліджуючи діяльнісний механізм розвитку методологічної культури учнів, ми встановили, що пріоритетним видом, який забезпечує формування всіх компонентів методологічної культури, зокрема й креативного та продуктивного, є творча навчально-пізнавальна діяльність [2].

Важливою категорією, яка стосується проєктування та організації творчої навчально-пізнавальної діяльності, є творча пізнавальна ситуація. Означене поняття дає можливість зрозуміти механізм ініціювання творчої навчально-пізнавальної діяльності, зокрема в контексті формування методологічної культури під час вивчення природничих предметів.

Аналіз наукових досліджень і публікацій. Зазвичай проблема організації творчої навчально-пізнавальної діяльності розглядається в контексті проблемного навчання. Принцип проблемності є одним із основоположних, коли йдеться про процес творчого пізнання. Він регламентує стратегію пізнавальної діяльності учнів за відомою схемою: виникнення проблемної ситуації $\rightarrow$ постановка проблеми $\rightarrow$ знаходження способу iї розв'язання шляхом здогадки або висунення та обгрунтування гіпотези $\rightarrow$ підтвердження гіпотези $\rightarrow$ перевірка правильності вирішення проблеми [9, с. 31].

Зважаючи на означене вище, в основу нашого дослідження покладено наукові праці, присвячені концепції проблемного навчання (О. Ляшенко, І. Лернер, О. Матюшкін, М. Махмутов); психології творчості (О. Пономарьов, О. Лук, І. Колошина); діяльнісному підходу в організації освітнього процесу (П. Гальперін, В. Давидов, Д. Ельконін, Г. Костюк, О. Леонтьєв, Н. Тализіна).

У науковій літературі $[1 ; 4 ; 6 ; 7 ; 10]$, присвяченій проблематиці творчого навчання, не існує однозначного тлумачення поняття творчої пізнавальної ситуації. Однак без розуміння її генезису, зв’язків з іншими категоріями, а також без виділення іiі істотних ознак моделювати творчу пізнавальну діяльність у навчальному процесі неможливо.
Мета статті - дослідити психолого-педагогічну суть творчої пізнавальної ситуації, визначити ऑiі основні типи, розкрити генезис, а також роль у процесі ініціювання навчально-пізнавальної діяльності.

Виклад основного матеріалу. Як відомо, початком творчого пізнавального процесу є проблемна ситуація. Її діалектичний зміст визначається навчально-пізнавальними суперечностями, які бувають досить різними: між раніше засвоєними знаннями та результатами спостереження, між життєвими уявленнями та науковими знаннями тощо [9]. Однак проблемна ситуація є лише необхідною умовою ініціювання творчого процесу. Для того, щоб учень став суб'єктом творчої навчально-пізнавальної діяльності, необхідно, щоб він сприйняв проблемну ситуацію, усвідомивши іiї у предметно-змістовому аспекті, який полягає у виокремленні суперечності між знанням i незнанням, відчув свою потенційну здатність вирішити дану ситуацію. Тобто суб'єкт має сприйняти ситуацію як власну навчальну проблему. При цьому також мають спрацьовувати пізнавальні мотиви.

Генезис творчої пізнавальної ситуації не обмежується створенням проблемної ситуації. Це поняття більш ширше і змістовніше як у психологічному, так i в дидактичному аспектах. Поглянемо на творчу пізнавальну ситуацію крізь призму рівневої моделі психологічного механізму творчої діяльності, у центрі якого - інтуїтивна здогадка і процес іiі формалізації [10]. Зрозуміло, що істотною ознакою (критерієм) творчої пізнавальної ситуації є відмінність структурних рівнів у постановці проблеми та у процесі ії вирішення.

Для більш грунтовного розуміння суті творчої пізнавальної ситуації розглянемо структуру творчої діяльності, представивши ії в такій декомпозиції: изілі, предмет, засоби, процедура, продукт, зовнішні умови [4]. Скористаємося поняттям «орієнтувальна основа діяльності» (далі - ООД), прийнятим у теорії поетапного формування розумових дій. Вказана дефініція поєднує в собі майже всі означені компоненти діяльності.

Відомо, що орієнтувальна основа діяльності може бути представлена трьома рівнями узагальнення. Відповідно компоненти діяльності також можуть мати різні рівні узагальнення [6, с. 47]. Засоби і процедура першого рівня узагальнення безпосередньо призначені для дослідження предмета діяльності і його перетворення у продукт. Таким чином вони є компонентами репродуктивної діяльності. Засоби і процедура другого рівня узагальнення - це зазвичай узагальнені теоретичні положення у відповідній предметній галузі, які дають змогу логічним шляхом отримати засоби і процедуру першого рівня узагальнення, тобто отримати конкретний спосіб перетворення предмета задачі в контексті досягнення поставленої вимоги (йдеться про спосіб розв'язування конкретної задачі). Натомість специфіка творчої пізнавальної діяльності полягає в тому, що її засоби і процедура представлені третім рівнем узагальнення. Їх здебільшого пов'язують із методологією - загальними методами наукового пізнання: моделюванням, застосуванням аналогії, ідеалізацією і формалізацією, уявним експериментом, сходженням від абстрактного до конкретного, зведенням конкретного до абстрактного, висуненням гіпотези тощо.

Істотною ознакою, яка відрізняє репродуктивну діяльність від творчої, є принципово різне представлення компонентів одного i того ж рівня узагальнення. До таких компонентів відносяться предмет і ціль діяльності [6, с. 50]. 
У репродуктивній діяльності предмет, як правило, завжди присутній у розгорнутому вигляді - iз виокремленням таких характеристик, які прямо чи опосередковано необхідні для досягнення цілі; у творчій діяльності предмет завжди представлений в інтегрованому, «спресованому» вигляді, в якому характеристики, необхідні для досягнення мети, себе не виявляють. Те ж саме стосується й цілі діяльності. Вона потребує додаткового розкриття, виявлення нових характеристик і внутрішніх елементів.

Отже, творча пізнавальна ситуація має місце тоді, коли компоненти пізнавальної діяльності (цілі, предмет, засоби, процедура) представлені на високому рівні узагальнення, тобто є частково невизначеними або латентними.

Аналіз засвідчує, що на основі генетичного підходу можна виокремити принаймні три типи творчих пізнавальних ситуацій, які розглянемо нижче.

1. Творча пізнавальна ситуація першого типу в iii основу покладено створену вчителем проблемну ситуацію, на підгрунті якої формулюється проблема, а потім - моделюється творча пізнавальна задача.

2. Творча пізнавальна ситуація другого типу - виникає на основі готової (внесеної ззовні) пізнавальної задачі, яка є творчою для учня.

3. Творча пізнавальна ситуація третього типу - постає і реалізується як прояв інтелектуальної (пізнавальної) ініціативи учня у процесі виконання репродуктивної діяльності. Такою діяльністю може бути виконання завдання, яке за своєю прямою ціллю не $є$ проблемним, але отриманий результат може спонукати учня до ініціювання виходу за межі заданого, як приклад - експеримент або навчальне спостереження на основі репродуктивної діяльності. У контексті означеного йдеться про інтелектуальну активність. Як відомо, вищим рівнем інтелектуальної активності вважається креативний. Наприклад, коли виявлене суб'єктом явище або закономірність стає для нього не просто евристикою, формальним прийомом, а самостійною проблемою. Відповідно така інтелектуальна активність розглядається не просто як доцільна адаптивна діяльність, а діяльність цілепокладання $[1$, с. 76$]$. На наш погляд, генезис інтелектуальної активності учня може бути представлений двома випадками: 1) причиною інтелектуальної ініціативи $є$ прямий продукт репродуктивної діяльності; 2) причиною для прояву інтелектуальної ініціативи $є$ побічний продукт репродуктивної діяльності.

Таким чином, для створення творчої пізнавальної ситуації третього типу необхідно забезпечити виконання таких вимог: 1) відсутність зовнішньої стимуляції пізнавальної діяльності, тобто відсутність вимоги ззовні; 2) відсутність «межі» в дослідженні (пізнанні) об'єкта; 3) достатність часу для того, щоб учень зміг проявити пізнавальну ініціативу; 4) забезпечення дворівневої пізнавальної діяльності за схемою: репродуктивна діяльність $\rightarrow$ творча .

Аналіз творчої ситуації буде неповним за умов, якщо iï не оцінити крізь призму такого поняття, як «пізнавальна домінанта». У психології під домінантою розуміють тимчасово домінуюче вогнище збудження в центральній нервовій системі. На нейрофізіологічному рівні - це здатність мозку формувати і тривалий час утримувати в стані збудження нейронну модель цілі, яка спрямовує процес мислення [7, с. 14]. Домінанта характеризується двома властивостями:
1) відносно високим збудженням групи нервових клітин, завдяки яким стимулюються подразники, що приходять із різних джерел; 2) стійкою затримкою збудження після припинення дії подразника. Ідея домінанти належить академіку О. Ухтомському. Оцінюючи роль домінанти в пізнавальному процесі, він писав (цитуємо мовою оригіналу): «...доминанта переживаемого момента $<\ldots>$ дает ученому то маховое колесо, «руководящую идею», «основную гипотезу», которые избавляют мысли от толчков и пестроты и содействуют сцеплению фактов в единый опыт» [11, с. 17].

У навчально-пізнавальній діяльності домінантами, які притягують до себе всі зовнішні подразники, можуть бути факти, думки, проблема, задача тощо. Отже, пізнавальна домінанта - це проблема, яка може бути породжена проблемною ситуацією, запропонованою ззовні задачею або ж інтелектуальною ініціативою, що є результатом аналізу окремих фактів. Домінанта притягує до себе всі зовнішні подразники. Потрапивши в «поле тяжіння» пізнавальної домінанти, такі подразники, як побічний продукт діяльності, підказка, допоміжна задача та ін., стають вагомими і «працюють» на вирішення проблеми. Зауважимо, що пошукова домінанта вважається однією із форм мотивації пізнавальної діяльності [10, с. 308].

Висновок. Таким чином, творча пізнавальна ситуація $\epsilon$ важливим чинником формування методологічної культури учнів у контексті реалізації діяльнісного підходу в освітньому процесі. Вона потребує вирішення деякого діалектичного протиріччя шляхом пошуку нового методу, прийому, засобу навчально-пізнавальної діяльності. Створення творчої пізнавальної ситуації $є$ механізмом ініціювання творчої навчально-пізнавальної діяльності. Водночас поняття «творча пізнавальна ситуація» не дублює поняття «проблемна ситуація», а є більш ширшим і змістовнішим як у психологічному, так і у дидактичному аспектах. Це стає зрозумілим за умов його розгляду в контексті відповідних психологічних концепцій творчої діяльності. Творча пізнавальна ситуація $є$ категорією суб'єктивною і характеризується наявністю в суб'єкта пізнавальної домінанти. Якщо пізнавальна домінанта згасає, то творча ситуація зникає і процес творчої пізнавальної діяльності припиняється. Це відбувається у двох випадках: 1) учень, проявивши пізнавальну ініціативу, сформулював проблему та успішно іiі розв'язав; 2) учень відмовився від іiі розв'язання.

\section{СПИСОК ВИКОРИСТАНОЇ ЛІТЕРАТУРИ}

1. Богоявленская Д. Б. Об одном из подходов к использованию интеллектуального творчества / Д. Б. Богоявленская // Вопросы психологии. - 1976. № 4. - С. 69-79.

2. Галатюк Т. Ю. Діяльнісний механізм розвитку методологічної культури учнів у процесі навчання фізики / Ю. М. Галатюк, М. Ю. Галатюк, Т. Ю. Галатюк // Вісник Чернігівського національного педагогічного університету. - Чернігів : ЧНПУ, 2013. Вип. 109. - С. 33-36. - (Серія «Педагогічні науки»).

3. Галатюк Т. Ю. Модель методологічної культури учня в контексті вивчення природничих предметів / Т. Ю. Галатюк // Збірник наукових праць Кам'янець-Подільського національного університету імені Івана Огієнка. - Кам'янець-Подільський : Кам'янець-Подільський національний університет імені Івана Огієнка, 2015. - Вип. 21. - С. 178-181. (Серія «Педагогічна»). 
4. Галатюк Ю. М. Концепція організації творчої навчально-пізнавальної діяльності з фізики в загальноосвітній школі / Ю. М. Галатюк // Збірник наукових праць Кам'янець-Подільського державного університету. - Кам'янець-Подільський : редакційно-видавничий відділ Кам'янець-Подільського державного університету, 2006. - Вип. 12. - С. 24-31. - (Серія «Педагогічна»).

5. Гоголева Ю. И. Педагогические условия становления методологической культуры учащихся : дис. ... кандидата пед. наук : 13.00.01 / Ю. И. Гоголева. - Псков, 2002. - 243 с.

6. Калошина И. П. Структура и механизм творческой деятельности / И. П. Калошина. - М. : Изд-во МГУ, 1983. - 168 с.

7. Лук А. Н. Психология творчества / А. Н. Лук. М. : Наука, 1978. - 126 с.
8. Лукашов В. С. Методологическая культура личности: понятие, структура, пути формирования (на материале подготовки военных инженеров) : дис. ... доктора философ. наук : 22.00 .06 / В. С. Лукашов. Санкт-Петербург, 1999. - 275 с.

9. Махмутов М. И. Организация проблемного обучения в школе. Книга для учителей / М. И. Махмутов. - М. : Просвещение, 1977. - 240 с.

10. Пономарёв Я. А. Психология творения / Я. А. Пономарёв. - Воронеж : Издательство НТО «МОДЭК», 1999. - 480 с.

11. Ухтомский А. А. Избранные труды / А. А. Ухтомский ; под ред. Е. М. Крепса. - Л. : Наука 1978. - 358 с.

12. Юдин Э. Г. Системный подход и принцип деятельности. Методологические проблемы современной науки / Э. Г. Юдин. - М. : Наука, 1978. - 392 с.

Дата надходження до редакиії: 03.10.2019 p.

Віталій ГЛАДУН,

старший викладач кафедри філософії освіти, теорії та методики суспільствознавчих предметів Миколаӥвського ОІППО

\section{ПАРТИСИПАЦІЯ УЧНІВСЬКОЇ МОЛОДІ ЯК СКЛАДОВА ФОРМУВАННЯ ГРОМАДЯНСЬКОЇ КОМПЕТЕНТНОСТІ}

У статті обтрунтовано процес формування громадянської компетентності учнівської молоді через партисипачію в освітньому середовищі. Розглянуто умови, щзо сприяють формуванню і розвитку особистості та ї̈ громадянського компонента.

Ключові слова: громадянська компетентність, учнівське самоврядування, учнівська молодь, демократія, партисипація.

В статье обоснован прочесс формирования гражданской компетентности учашейся молодежи через партисипацию в образовательной среде. Рассмотрены условия, что способствуют формированию и развитию личности и ее гражданского компонента.

Ключевые слова: гражданская компетентность, ученическое самоуправление, учамаяся молодежь, демократия, партисипация.

The article substantiates the process of civic competence formation of student youth through participation in the educational environment. The problem of civic competence formation among students was covered by the domestic and foreign researchers from different views. American educators have played a leading role in the study and implementation of the civic engagement among youth and they understand this process as a means of educating a law-abiding citizen of their own state and at the same time a competent, full-fledged citizen of the world. Most scholars believe that the conditions should be created in schools to involve children in the work at children and youth organizations, which contribute to the development of a person and one's civic component.

The experience of Canada and the USA is analyzed about the students active participation, when they do not stay away from the society's democratic processes, but on the contrary, while schooling they are involved in the analysis of socio-political problems through understanding of democratic values, they learn to analyze the results of government policy, to acquire the essential information to define their own position.

Particular attention should be paid to the consideration of the European Charter about the participation of young people in a public life at regional levels. Participation in a political and cultural life is one of the fundamental human rights recognized in a number of international human rights treaties, including the Universal Declaration of Human Rights. Participation is also one of the fundamental principles of the Convention on the Rights of the Child. Accordingly many human rights are difficult to access without the participation. Youth participation is not an end in itself, but a means of achieving a positive change in young people's lives and building a better society. The main ways of student youth participation are revealed and the reasons to develop the participation skills at school are identified. 